DOI 10.18551/rjoas.2021-10.18

\title{
THE EFFECT OF INTERNAL CONTROL ON CREDIT DISTRIBUTION EFFICIENCY
}

\author{
Anggiriawan Putu Budi*, Putra I Wayan Gde Yogiswara Darma \\ Warmadewa University, Indonesia \\ *E-mail: budianggiriawan@gmail.com
}

\begin{abstract}
Efficiency of credit distribution is used to measure the extent to which LPD's ability to manage human resources in order to increase profit through credit management. The efficiency or not of credit distribution is calculated using indicators including the credit distribution system, credit disbursement system and the credit monitoring system that has been disbursed. Internal control is designed to provide reasonable assurance about the state of the financial statements, compliance with applicable regulations, effective and efficient operations. Based on the explanation above, the writer's curiosity arises to research further on "The Influence of Internal Control Structure on Credit Distribution Efficiency". Based on data obtained from the Trustees of the Badung Regency Village Credit Institution (PLPDK), the LPDs that are still operating in Abiansemal District are 34 LPDs where the head and LPD supervisory bodies are respondents. The data analysis method in this study uses multiple regression analysis to obtain a comprehensive picture of the effect of the variables of transparency, accountability, responsibility, independence, and fairness on financial performance using the SPSS for windows program. The results showed that internal control (control environment, control activities, risk assessment, information and communication, and monitoring) had a positive and significant effect on the efficiency of credit distribution. When the LPD's internal control is good and adequate, the efficiency of credit distribution is also fulfilled, in the sense that the risk of bad loans can be minimized.
\end{abstract}

\section{KEY WORDS}

Internal control, efficiency of credit distribution, LPD.

The Village Credit Institution (LPD) is a non-bank financial institution that is the embodiment of the traditional village community. Since it was initiated in November 1984 by the Governor of Bali, which at that time was held by Prof. Dr. Ida Bagus Mantra (late), LPD has carried out the function of encouraging community economic development through targeted savings, as well as effective distribution of capital. LPD is also expected to be able to eradicate the bondage system and illegal pawning, which at that time often occurred in the community. Another function that is also carried out is to create equal distribution and employment opportunities for rural residents, both those who can work directly in the LPD or who can be accommodated by the productive efforts of the community financed by the LPD. Creating purchasing power, as well as facilitating payment and exchange traffic in the village, are also the main tasks of the LPD.

Internal control is a process carried out by the board of commissioners, management and other personnel designed to provide reasonable assurance about the state of the financial statements, compliance with applicable regulations, effective and efficient operations (Mulyadi, 2016). The Committee of Sponsoring Organization (COSO) stated that internal control is in the basic management process, namely planning, implementation, and monitoring. There are five components of the internal control structure, namely: (1) control environment, (2) risk assessment, (3) control activities, (4) information and communication, and (5) monitoring (Halim, 2015:214)

There are differences in the results of research conducted by Parameswara, et al. (2018) and Rupadi (2019) stated that the Control Environment, Risk Assessment, Control Activities, Information and Communication, and Monitoring had a positive effect on the Efficiency of Credit Distribution. This is in contrast to research conducted by Dewi Purnawasih (2019) which states that the Control Environment, Risk Assessment, Control 
Activities, Information and Communication have no effect on the Efficiency of Credit Distribution. However, Monitoring and Information and Communication have a positive effect on Credit Distribution.

The increase in lending will affect the income received by the LPD due to the receipt of loan interest payments. Conversely, if the level of lending decreases, it will have an impact on decreasing income because there is no receipt of credit interest payments. The credit distribution process of an LPD must pay attention to management aspects in implementing credit distribution. Credit supervision is one of the control systems that can be implemented. The internal control structure aims to be able to avoid unhealthy lending and abuse of authority in LPDs. Internal control is the first gate that is able to prevent misstatements (Wilatini, 2019).

The inconsistency obtained from the results of previous research, the author's curiosity arises to research further on "Control Environment, Risk Assessment, Control Activities, Information and Communication, and Monitoring of Credit Distribution Efficiency". The location of the research is LPD in Abiansemal District, the choice of LPD in Abiansemal District cannot be separated from issues, phenomena and motivations. Based on what has been described, a research entitled "The Influence of Internal Control Structures on the Efficiency of Credit Distribution at the Village Credit Institution (LPD) in Abiansemal District is carried out".

\section{LITERATURE REVIEW}

Agency theory (agency theory) according to Jasen and Meckling (1976) is to explain the relationship between owner and management in a company. An agency relationship exists when one party (principal) hires another party (agent) to perform some services. The service requires the principal to delegate some decision-making authorization to the agent. Agency theory is the basis for understanding the concept of Corporate Governance. In an agency relationship, there may be conflicts between participants and agents. Conflict can be caused because the agent does not act in accordance with the wishes of the participant so that this can trigger agency costs (Abdul Halim, 2015: 233).

Based on agency theory, LPD management is carried out separately by village manners so that there is the possibility of agency conflicts. When disbursing credit to an LPD, there is a conflict of interest between the principal (the LPD) and the agent (the debtor), where the agent (the debtor) may not comply with the agreement in carrying out its obligations. This of course will cause a problem for the principal (the LPD) who is threatened with bad credit problems because the agent (debtor) does not carry out its obligations in accordance with the agreement that has been made and agreed in advance.

According to Mardiasmo (2009) efficiency is the achievement of maximum output by using input, where efficiency is a comparison of output and input related to performance standards or set targets. With the use of the lowest possible input that produces the maximum output, it can be said to be efficiency. Therefore, the efficiency of credit distribution is the ability of the LPD to earn income through the management of human resources in managing credit. Income from the efficiency of lending affects the profitability of LPD.

The efficiency of credit distribution is used as a sample measure of the extent to which LPD's ability to increase profit through the management of its human resources, especially from the credit department. The amount of efficiency in lending will indirectly affect the overall profit because if the LPD is more efficient in lending, it will be able to minimize nonperforming loans in the LPD.

Committee of Sponsoring Organization of The Treadway Commission (COSO) in 1992 issued a definition of internal control. COSO's definition of internal control is as follows: Internal control is process, affected by entity's board of directors, management and other personnel, designed to provide reasonable assurance regarding the achievement of objectives in the following categories: Effectiveness and efficiency of operations, Reliability of Financial Reporting, and Compliance with Applicable laws and regulations. From this definition, the internal control system is a process involving the board of commissioners, 
management, and other personnel, designed to provide reasonable assurance about the effectiveness and efficiency of operations, reliability of financial reporting and compliance with applicable laws and regulations.

Based on the Committee of Sponsoring Organizations (COSO) there are five components of the internal control structure, namely:

- Control Environment. It is a set of standards, processes and structures that provide the basis for the implementation of internal control within the organization;

- Risk Assessment. Risk assessment involves a dynamic and iterative process to identify and analyze risks related to the achievement of objectives;

- Control Activities. Control activities include actions established through policies and procedures to help ensure that management directives are implemented in order to minimize risks to the achievement of objectives;

- Information and Communication. Organizations need information for the implementation of the internal control function in supporting the achievement of objectives;

- Monitoring. This component is the only component that has changed its name. Previously this component was only called monitoring.

\section{HYPOTHESIS DEVELOPMENT}

According to COSO, the control environment is a set of standards, processes and structures that provide the basis for the implementation of internal control within the organization. The control environment includes standards, processes, and structures that form the basis for the implementation of internal control within the organization as a whole. The results of previous research conducted by Parameswara, et al. (2018), Rupadi (2019) and Virnawan and Cahyadi (2014) show that the control environment has a positive effect on the efficiency of credit distribution. Based on the theory and previous research, the researcher proposes the following hypothesis:

$\mathrm{H} 1$ : Control Environment has a positive effect on the Efficiency of Credit Distribution at LPDs in Abiansemal District.

According to COSO, risk assessment is the identification of an entity and an analysis of the risks relevant to achieving its objectives, forming a basis for determining how risks should be managed. Determination of risk for the purpose of financial statements is the identification of the organization, analysis, and management of risks related to the preparation of financial statements that are presented in accordance with generally accepted accounting principles. Risk management analyzes the risk relationship of specific financial statement assertions with activities such as recording, processing, summarizing, and reporting financial data (Halim, 2015: 215). The results of previous research conducted by Parameswara, et al. (2018), Rupadi (2019) and Virnawan and Cahyadi (2014) show that risk assessment has a positive effect on credit distribution efficiency.

H2: Risk Assessment has a positive effect on the Efficiency of Credit Distribution at LPDs in Abiansemal District.

According to COSO, control activities are policies and procedures, in addition to those covered by the other four control components, that assist in ensuring that the necessary actions are taken to address risks in order to achieve the entity's objectives. Control activities have a variety of purposes and are applied at various organizational and functional levels. The results of previous research conducted by Parameswara, et al. (2018), Rupadi (2019) and Virnawan and Cahyadi (2014) show that control activities have a positive effect on the efficiency of credit distribution. Based on the theory and previous research, the researcher proposes the following hypothesis:

H3: Control Activities have a positive effect on the Efficiency of Credit Distribution at LPDs in Abiansemal District.

According to COSO, information and communication is the identification, capture and exchange of information in a form and timeframe that enables people to carry out their responsibilities. Relevant information systems in financial reporting which include accounting 
systems that contain methods for identifying, combining, analyzing, classifying, recording, and reporting transactions as well as maintaining accountability for assets and liabilities. Communication includes providing descriptions of individual duties and responsibilities relating to the internal control structure in financial reporting. The results of previous research conducted by Parameswara, et al. (2018), Virnawan and Cahyadi (2014), and Purwasih (2019) and Rupadi (2019) show that information and communication have a positive effect on credit distribution efficiency.

H4: Information and Communication have a positive effect on the Efficiency of Credit Distribution at LPDs in Abiansemal District.

Monitoring is a process that determines the quality of internal control performance over time. Monitoring includes determining the design and operation of controls on time and taking corrective actions (Halim, 2015:221). Monitoring activities can include the use of information derived from communication with external parties that can indicate problems or areas of concern that require improvement (Haryono, 2014:375). Through monitoring, personnel can assess the design and operation of scheduled controls and can take appropriate action. The results of previous research conducted by Parameswara, et al. (2018), Rupadi (2019) and Purwasih (2019) show that monitoring has a positive effect on the efficiency of credit distribution.

H5: Monitoring has a positive effect on the efficiency of credit distribution at LPDs in Abiansemal District.

\section{METHODS OF RESEARCH}

Based on the theory and empirical studies above, this research formulates 1 hypothesis and the data analysis technique used is linear regression analysis. The location of the research was carried out at the Village Credit Institution in Abiansemal District, Badung Regency. The object of this study is the internal control of the efficiency of lending to the LPD.

Based on data obtained from the Trustees of the Badung Regency Village Credit Institution (PLPDK), there are 34 LPDs still operating in Abiansemal District. Researchers use the entire population as a sample or what is known as a saturated sampling technique. Respondents selected in this study were the head of the LPD and the LPD supervisory body.

The dependent variable in this study is the Efficiency of Credit Distribution, namely the achievement of maximum output by using inputs, where efficiency is a comparison of output and input related to performance standards or targets set. The independent variables are the control environment, risk assessment, control activities, information and communication, and monitoring.

Quantitative data in the form of the results of respondents' answers in the form of scores on the questions in the questionnaire. While qualitative data such as a brief history of the Village Credit Institution (LPD) and organizational structure. The data collection method in this study used two ways, namely using a questionnaire and documentation in the form of a list of the number of LPDs and LPD financial reports.

The data analysis method in this study uses regression analysis to obtain a comprehensive picture of the effect of the variables of transparency, accountability, responsibility, independence, and fairness on financial performance using the SPSS for windows program.

The data analysis test begins with testing the research instrument, namely by testing the validity and reliability of the instrument, considering that the questionnaire is an important instrument in this study. Valid and reliable instruments are an absolute requirement to obtain relevant research results.

Before the regression model is used to test the hypothesis, the classical assumption is first tested using the normality test, multicollinearity test, and heteroscedasticity test.

The data analysis tool used is statistical inference which aims to test the hypothesis by using Linear Regression through the SPSS computer program with the following formula: 


$$
Y=a+b 1 X 1+b 2 X 2+b 3 X 3+b 4 X 4+b 5 X 5 e(1)
$$

Where:

$Y=$ Dependent variable (Efficiency of lending);

$\mathrm{a}=$ constant;

b1, b2, b3, b4, b5 = Regression coefficients for X1, X2, X3, X4, X5;

$\mathrm{X} 1$ = Independent variable (control environment);

$\mathrm{X} 2$ = Independent variable (control risk);

X3 = Independent variable (control activity);

X4 = Independent variable (information and communication);

X5 = Independent variable (monitoring);

$\mathrm{e}=$ Intruder error (Standard Error).

To complete this data analysis as a whole, the SPSS program is used and all the output data results are then interpreted one by one including determining the correlation coefficient $(R)$ to measure the level of relationship between the independent variable and the dependent variable and the coefficient of determination $(R 2)$ to measure the influence between the independent variable and the dependent variable.

Ghozali (2018: 97) states that the accuracy of the sample regression function in estimating the actual value can be measured from its goodness of fit. Statistically it can be measured from the value of the coefficient of determination (R2), the F statistical test, and the t statistical test.

\section{RESULTS AND DISCUSSION}

Control Environment has a minimum value of 56, a maximum value of 65 and an average value of 59.53. The standard value of the Control Environment is 2,004.

The Risk Assessment has a minimum value of 57, a maximum value of 64 and an average value of 60.63. The standard deviation of the Risk Assessment is 1.860 .

Control Activities have a minimum value of 56, a maximum value of 64 and an average value of 59.65. The standard deviation of Control Activities is 2.072.

Information and Communication has a minimum score of 55, a maximum value of 64 and an average value of 58.93. The standard deviation value of Control Activities is 1.942.

Monitoring has a minimum value of 56 , a maximum value of 65 and an average value of 58.92. Monitoring standard deviation value of 2.137.

Credit Distribution Efficiency has a minimum score of 86, a maximum value of 97 and an average value of 90.84 . The standard deviation of Credit Channelling Efficiency is 2.341.

Table 1 - Descriptive Statistical Analysis Test

Descriptive Statistics

\begin{tabular}{llllll}
\hline & $\mathrm{N}$ & Minimum & Maximum & mean & Std. Deviation \\
\hline Control Environment & 68 & 56 & 65 & 59.53 & 2004 \\
Risk Assessment & 68 & 57 & 64 & 60.63 & 1,860 \\
Control Activities & 68 & 56 & 64 & 59.65 & 2.072 \\
Information and Communication & 68 & 55 & 64 & 58.93 & 1,942 \\
Monitoring & 68 & 56 & 65 & 59.82 & 2.137 \\
Credit Distribution Efficiency & 68 & 86 & 97 & 90.84 & 2,341 \\
\hline Valid N (listwise) & 68 & & &
\end{tabular}

Table 2 - Normality test

\begin{tabular}{ll}
\hline & Unstandardized Residual \\
\hline Asymp. Sig. (2-tailed) & $.200 \mathrm{c}, \mathrm{d}$ \\
\hline
\end{tabular}

The results of the normality test showed a significant value of Asymp. Sig. (2-tailed) of $0.200>0.050$. It can be concluded that the data used in this study is data that is normally distributed. 
Table 3 - Heteroscedasticity Test

\begin{tabular}{lll}
\hline Variable & Sig. & Information \\
\hline Control Environment & 0.789 & Heteroscedasticity Free \\
Risk Assessment & 0.477 & Heteroscedasticity Free \\
Control Activities & 0.369 & Heteroscedasticity Free \\
Information and Communication & 0.665 & Heteroscedasticity Free \\
Monitoring & 0.909 & Heteroscedasticity Free \\
\hline
\end{tabular}

The results of the heteroscedasticity test show that all variables have a significance value exceeding 0.05 so that the research data can be concluded to be free from heteroscedasticity.

Table 4 - Multicollinearity Test

Coefficients $^{a}$

\begin{tabular}{|c|c|c|c|c|c|c|}
\hline \multirow[b]{2}{*}{ Model } & \multicolumn{2}{|c|}{$\begin{array}{l}\text { Unstandardized } \\
\text { Coefficients }\end{array}$} & \multirow{2}{*}{$\begin{array}{l}\text { Standardized } \\
\text { Coefficients } \\
\text { Beta }\end{array}$} & \multicolumn{3}{|c|}{$\begin{array}{l}\text { Collinearity } \\
\text { Statistics }\end{array}$} \\
\hline & B & Std. Error & & $\mathrm{t}$ & Sig. Tolerance & VIF \\
\hline 1 (Constant) & 13.126 & 7.251 & & & 0.075 & \\
\hline Control Environment & .290 & .110 & .248 & & 9.010 .615 & 1,627 \\
\hline Risk Assessment & .273 & .109 & .217 & & 5.015 .718 & 1.393 \\
\hline Control Activities & .285 & .112 & .252 & & 8.013 .551 & 1.816 \\
\hline $\begin{array}{l}\text { Information } \\
\text { Communication }\end{array}$ & and .261 & .112 & .216 & & 8.024 .621 & 1,611 \\
\hline Monitoring & .192 & .089 & .175 & & 1.035 .815 & 1,227 \\
\hline
\end{tabular}

a. Dependent Variable: Credit Distribution Efficiency.

Based on the table, it is known that the Tolerance value of the Control Environment variable is 0.615 , Risk Assessment is 0.718 , Control Activities, 0.551 Information and Communication is 0.621 and Monitoring is 0.815 greater than 0.10 . Meanwhile, the VIF value of the Control Environment variable is 1.627, Risk Assessment is 1.393, Control Activities, 1.816, Information and Communication is 1.611 and Monitoring is 1.227 smaller than 10.00 . So it can be concluded that there is no multicollinearity.

Table 5 - Validity and Reliability Test - Control Environment (X1)

\begin{tabular}{llllllll}
\hline & Item 1 & Item 2 & Item 3 & Item 4 & Item 5 & Item 6 & Item 7 \\
\hline Control Environment & .573 & .403 & .392 & .496 & .408 & .427 & .323 \\
\hline
\end{tabular}

Validity testing is done by comparing the Pearson Correlation $r$ table with the SPSS test results. Based on table $r$ the Pearson correlation with a significance level of $5 \%$ with a sample of 68 is 0.235 . The results of the validity test of the Control Environment variable for each question item are item 1 of 0.573 , item 2 of 0.403 , item 3 of 0.392 , item 4 of 0.496 , item 5 of 0.408 , item 6 of 0.427 and item 7 of 0.323 . All items have a value greater than 0.235 so that the data used is valid.

Table 6 - Reliability Test

\begin{tabular}{ll}
\hline Cronbach's Alpha & $\mathrm{N}$ of items \\
\hline .642 & 8 \\
\hline
\end{tabular}

Cronbach's Alpha shows a value of 0.642 which is greater than 0.60 so that the data used is reliable.

Table 7 - Validity and Reliability Test - Risk Assessment (X2)

\begin{tabular}{llllllll}
\hline & Item 1 & Item 2 & Item 3 & Item 4 & Item 5 & Item 6 & Item 7 \\
\hline Risk Assessment & .326 & .533 & .323 & .503 & .498 &, 330 &, 416 \\
\hline
\end{tabular}


Validity testing is done by comparing the Pearson Correlation $r$ table with the SPSS test results. Based on table $r$ the Pearson correlation with a significance level of $5 \%$ with a sample of 68 is 0.235 . The results of the validity test of the Risk Assessment variable for each question item are item 1 of 0.326 , item 2 of 0.533 , item 3 of 0.323 , item 4 of 0.503 , item 5 of 0.498 , item 6 of 0.330 and item 7 of 0.416 . All items have a value greater than 0.235 so that the data used is valid.

Table 8 - Reliability Test

\begin{tabular}{ll}
\hline Cronbach's Alpha & N of items \\
\hline .619 & 8 \\
\hline
\end{tabular}

Cronbach's Alpha shows a value of 0.619 which is greater than 0.60 so that the data used is reliable.

Table 9 - Validity and Reliability Test - Control Activities (X3)

\begin{tabular}{llllllll}
\hline & Item 1 & Item 2 & Item 3 & Item 4 & Item 5 & Item 6 & Item 7 \\
\hline Control Activities & .349 & .458 & .425 & .400 & .507 & .509 & .401 \\
\hline
\end{tabular}

Validity testing is done by comparing the Pearson Correlation $r$ table with the SPSS test results. Based on table $r$ the Pearson correlation with a significance level of $5 \%$ with a sample of 68 is 0.235 . The results of the validity test of the Control Activities variable for each question item are item 1 of 0.349 , item 2 of 0.458 , item 3 of 0.425 , item 4 of 0.400 , item 5 of 0.507 , item 6 of 0.509 and item 7 of 0.401 . All items have a value greater than 0.235 so that the data used is valid.

Table 10 - Reliability Test

\begin{tabular}{ll}
\hline Cronbach's Alpha & N of items \\
\hline .635 & 8 \\
\hline
\end{tabular}

Cronbach's Alpha shows a value of 0.635 which is greater than 0.60 so that the data used is reliable.

Table 11 - Validity and Reliability Test - Information and Communication (X4)

\begin{tabular}{llllllll}
\hline & Item 1 & Item 2 & Item 3 & Item 4 & Item 5 & Item 6 & Item 7 \\
\hline Information and Communication & .424 & .321 & .252 & .416 & .462 & .574 & .472 \\
\hline
\end{tabular}

Validity testing is done by comparing the Pearson Correlation $r$ table with the SPSS test results. Based on table $r$ the Pearson correlation with a significance level of $5 \%$ with a sample of 68 is 0.235 . The results of the validity of the Information and Communications variable validity test for each question item, namely item 1 of 0.424 , item 2 of 0.321 , item 3 of 0.252 , item 4 of 0.416 , item 5 of 0.462 , item 6 of 0.574 and item 7 of 0.472 . All items have a value greater than 0.235 so that the data used is valid.

Table 12 - Reliability Test

\begin{tabular}{ll}
\hline Cronbach's Alpha & $\mathrm{N}$ of items \\
\hline .624 & 8 \\
\hline
\end{tabular}
reliable.

Cronbach's Alpha shows a value of 0.770 greater than 0.70 so the data used is

Table 13 - Validity and Reliability Test - Monitoring (X5)

\begin{tabular}{llllllll}
\hline & Item 1 & Item 2 & Item 3 & Item 4 & Item 5 & Item 6 & Item 7 \\
\hline Monitoring & .392 & .262 & .521 & .354 & .444 & .487 & .511 \\
\hline
\end{tabular}


Validity testing is done by comparing the Pearson Correlation $r$ table with the SPSS test results. Based on table $r$ the Pearson correlation with a significance level of $5 \%$ with a sample of 68 is 0.235 . The results of the validity test of the Monitoring variables for each question item are item 1 of 0.392 , item 2 of 0.262 , item 3 of 0.521 , item 4 of 0.354 , item 5 of 0.444 , item 6 of 0.487 and item 7 of 0.511 . All items have a value greater than 0.235 so that the data used is valid.

Table 14 - Reliability Test

\begin{tabular}{ll}
\hline Cronbach's Alpha & $\mathrm{N}$ of items \\
\hline .630 & 8 \\
\hline
\end{tabular}

Cronbach's Alpha shows a value of 0.630 which is greater than 0.60 so that the data used is reliable.

Table 15 - Validity and Reliability Test - Credit Distribution Efficiency (Y)

\begin{tabular}{lccccccccccc}
\hline & Item 1 & Item 2 & Item 3 & Item 4 & Item 5 & Item 6 & Item 7 & Item 8 & Item 9 & Item 10 & Item 11 \\
\hline $\begin{array}{l}\text { Credit Distribution } \\
\text { Efficiency }\end{array}$ & .410 & .268 & .380 & .385 & .438 & .263 & .320 & .319 & .413 & .325 & .331 \\
\hline
\end{tabular}

With SPSS test results. Based on table $r$ the Pearson correlation with a significance level of $5 \%$ with a sample of 68 is 0.235 . The results of the validity test of the Credit Distribution Efficiency variable for each question item, namely item 1 of 0.410 , item 2 of 0.268 , item 3 of 0.380 , item 4 of 0.385 , item 5 of 0.438 , item 6 of 0.263 , item 7 of 0.320 , item 8 of 0.319 , item 9 of 0.413 , item 10 of 0.325 , and item 11 of 0.331 . All items have a value greater than 0.235 so that the data used is valid.

Table 16 - Reliability Test

\begin{tabular}{ll}
\hline Cronbach's Alpha & $\mathrm{N}$ of items \\
\hline .616 & 12 \\
\hline
\end{tabular}

Cronbach's Alpha shows a value of 0.616 which is greater than 0.60 so that the data used is reliable.

Table 17 - Multiple Linear Regression Analysis Test

\begin{tabular}{|c|c|c|c|c|}
\hline \multirow[b]{2}{*}{ Model } & \multicolumn{2}{|c|}{ Unstandardized Coefficients } & \multicolumn{2}{|c|}{ Standardized Coefficients } \\
\hline & $\mathrm{B}$ & Std. Error & Beta & Sig. \\
\hline 1 (Constant) & 13.126 & 7.251 & & $1,810.075$ \\
\hline Control Environment & .290 & .110 & .248 & $2,649.010$ \\
\hline Risk Assessment & .273 & 109 & .217 & 2.505 .015 \\
\hline Control Activities & .285 & .112 & .252 & 2,548.013 \\
\hline Information and Communication & 261 & .112 & .216 & 2.318 .024 \\
\hline Monitoring & .192 & .089 & .175 & 2.151 .035 \\
\hline
\end{tabular}

a. Dependent Variable: Credit Distribution Efficiency.

$$
Y=13.126+0.290 \times 1+0.273 \times 2+0.285 \times 3+0.261 X 4+0.192 \times 5+e
$$

The constant value of 13.126 indicates that if the variables of Control Environment, Risk Assessment, Control Activities, Information and Communication and Monitoring are equal to zero, then the value of Credit Distribution Efficiency $(Y)$ is positive 13.126 units.

The coefficient value of 1 in the Control Environment (X1) of 0.290 has a positive relationship on Credit Distribution Efficiency. This means that if the Control Environment (X1) increases, there will be an increase in Credit Distribution Efficiency ( $Y$ ) of 0.290 units assuming other independent variables are held constant.

The coefficient value of 2 in the Risk Assessment (X2) of 0.273 has a positive relationship on Credit Distribution Efficiency. This means that if the Risk Assessment (X2) 
increases, there will be an increase in Credit Distribution Efficiency ( $Y$ ) of 0.273 units assuming other independent variables are considered constant.

The value of the coefficient of 3 in Controlling Activities (X3) of 0.285 has a positive relationship on Credit Distribution Efficiency. This means that if the Controlling Activity (X3) increases, there will be an increase in Credit Distribution Efficiency ( $Y$ ) of 0.285 units assuming the other independent variables are held constant.

The coefficient value of 4 on Information and Communication (X4) of 0.261 has a positive relationship on Credit Distribution Efficiency. Means indicate that if Information and Communication (X4) increases, there will be an increase in Credit Distribution Efficiency ( $\mathrm{Y}$ ) of 0.261 units assuming other independent variables are held constant.

The coefficient value of 5 on Monitoring (X5) of 0.192 has a positive relationship on Credit Distribution Efficiency. This means that if Monitoring (X5) increases, there will be an increase in Credit Distribution Efficiency $(\mathrm{Y})$ of 0.192 units assuming other independent variables are considered constant.

Table 18 - Coefficient of determination test (R2)

Model Summary

\begin{tabular}{lllll}
\hline Model & $\mathrm{R}$ & $\mathrm{R}$ Square & Adjusted R Square & Std. Error of the Estimate \\
\hline 1 & $.816 \mathrm{a}$ & .665 & .638 & 1,408 \\
\hline
\end{tabular}

a. Predictors: (Constant), Monitoring, Risk Assessment, Control Activities, Control Environment, Information and Communication.

Adjusted $R$ Squareof 0.638 means that $63.8 \%$ of Credit Distribution Efficiency is influenced by the Control Environment, Risk Assessment, Control Activities, Information and Communication and Monitoring. The remaining $36.2 \%$ is influenced by other variables that are not included in the model.

Table $19-\mathrm{F}$ Uji test

ANOVA $^{a}$

\begin{tabular}{|c|c|c|c|c|c|c|}
\hline \multirow{4}{*}{$\frac{\text { Model }}{1}$} & & Sum of Squares & df & Mean Square & $\mathrm{F}$ & Sig. \\
\hline & Regression & 244.231 & 5 & 48,846 & 24,624 & $.000 \mathrm{~b}$ \\
\hline & Residual & 122,989 & 62 & 1984 & & \\
\hline & Total & 367,221 & 67 & & & \\
\hline
\end{tabular}

a. Dependent Variable: Credit Distribution Efficiency.

b. Predictors: (Constant), Monitoring, Risk Assessment, Control Activities, Control Environment, Information and Communication.

Based on the table the significant level used is 0.05 . The significant value of $F$ or $p$ value is 0.000 which indicates that the value is smaller than 0.05 . This shows that the model is able to predict the research phenomenon.

Table $20-t$ test

Coefficients $^{a}$

\begin{tabular}{lllll}
\hline Model & \multicolumn{2}{l}{ Unstandardized Coefficients } & \multicolumn{2}{l}{ Standardized Coefficients } \\
Beta & t & Sig. \\
\hline 1(Constant) & B & Std. Error & $1,810.075$ \\
Control Environment & 13.126 & 7.251 & .248 & $2,649.010$ \\
Risk Assessment & .290 & .110 & .217 & 2.505 .015 \\
Control Activities & .273 & .109 & .252 & $2,548.013$ \\
Information and Communication & .285 & .112 & .216 & 2.318 .024 \\
Monitoring & .261 & .112 & .175 & 2.151 .035 \\
\hline
\end{tabular}

a. Dependent Variable: Credit Distribution Efficiency.

H1 Testing. The regression coefficient value of the Control Environment variable is 0.290. The significance value of the Controlling Environment is $0.010<0.05$, which means that the $\mathrm{t}$ value is significant so that $\mathrm{H} 1$ which states that the Control Environment has a 
positive effect on the Efficiency of Credit Distribution is acceptable.

H2 Testing. The regression coefficient value of the Risk Assessment variable is 0.273. The significance value of integrity is $0.015<0.05$, which means that the t value is significant so that $\mathrm{H} 2$ which states that Risk Assessment has a positive effect on Credit Distribution Efficiency can be accepted.

H3 Testing. The regression coefficient value of the Control Activity variable is 0.285 . The significance value of Control Activities is $0.013<0.05$, which means the $t$ value is significant so that $\mathrm{H} 3$ which states that Control Activities have a positive effect on Credit Distribution Efficiency is acceptable.

H4 Testing. The regression coefficient value of the Information and Communication variable is 0.261 . The significance value of Information and Communication is $0.024<0.05$, which means the $\mathrm{t}$ value is significant so that $\mathrm{H} 4$ which states that Information and Communication has a positive effect on Credit Distribution Efficiency is acceptable.

H5 Testing. The regression coefficient value of the Monitoring variable is 0.192 . The significance value of Information and Communication is $0.035<0.05$, which means the $t$ value is significant so that $\mathrm{H} 5$ which states that Monitoring has a positive effect on Credit Distribution Efficiency can be accepted.

\section{CONCLUSION}

The control environment has a positive effect on the efficiency of lending at the Village Credit Institution (LPD) in Abiansemal District. The existence of an organizational structure provides an overview of the duties and rights of each personnel in the LPD. Especially in the credit section where credit control is prioritized on the LPD and risks in the credit section are carefully considered and adequately monitored.

Risk assessment has a positive effect on the efficiency of credit distribution at the Village Credit Institution (LPD) in Abiansemal District. At the time of disbursement of credit, a risk assessment of the possibility of default from the customer must be carried out. It aims to adjust the customer's ability to pay so that default does not occur.

Control activities have a positive effect on the efficiency of credit distribution at the Village Credit Institution (LPD) in Abiansemal District. The separation of functions such as transactions, administrative operations and storage carried out at the Village Credit Institution (LPD) as well as financial reports completed in a timely manner is able to make credit distribution efficient.

Information and communication have a positive effect on the efficiency of credit distribution at the Village Credit Institution (LPD) in Abiansemal District. An adequate information system will help provide information for LPD management in assessing the efficiency of lending.

Monitoring has a positive effect on the efficiency of credit distribution at the Village Credit Institution (LPD) in Abiansemal District. Good monitoring is able to evaluate that the internal control at the Village Credit Institution (LPD) has been operating effectively, and with good monitoring will help take appropriate action as well. Because if the monitoring carried out on the LPD is better, it will be able to increase the efficiency of lending to the LPD.

\section{SUGGESTIONS}

Further researchers are expected to complete the interview and survey methods which aim to increase the attitude of the respondents' seriousness and concern in answering questions and replace the risk assessment variables and information and communication by adding or developing other variables such as lending strategies, capital structure and conditions of prospective debtors that affect efficiency.

For Village Credit Institutions (LPD) in Abiansemal District, it is hoped that they will get input and considerations from this research regarding the efficiency of credit distribution by providing continuous guidance to LPD management. As well as being able to improve understanding and implementation of credit disbursement efficiency in the application of 
internal control components, namely the control environment, risk assessment, control activities, information and communication and monitoring in order to run optimally in lending.

The collection of questionnaire data in this study can be said to be relatively long because it faces several obstacles, such as being hampered by the location of the LPD which is quite far apart, and filling out the answers to the questionnaire from the LPD that has passed the requested time. The use of electronic questionnaires is highly recommended in further research in order to simplify and speed up the data collection process.

\section{REFERENCES}

1. COSO. (2013). Internal Control - Integrated Framework. Accessed on November 18, 2020, https://www.coso.org/

2. Halim, PA (2015). Auditing (Fundamentals of Auditing Financial Statements). Yogyakarta: Publishing and Printing Unit YKPN College of Management.

3. Ghozali, I. (2018). Applications of Multivariate Analysis with IBM SPSS 25 Program, 9th Edition. Semarang: BP UNDIP.

4. Jensen, Michael C. and Meckling, William H. (July 1, 1976), Theory of the Firm: Managerial Behavior, Agency Costs and Ownership Structure.

5. Mardiasmo, PD (2009). Public sector accounting . Yogyakarta: CV ANDI OFFSET (ANDI Publisher).

6. Mulyadi. (2016). Accounting information system. Jakarta: Four Salemba.

7. Norwani, Norlia M., ZamZuriyati Mohamad, and Ibrahim TambyChek. 2011. Corporate Governance Failure and Its Impact on Financial Reporting Within Selected Companies. International Journal of Business and Social Science, 2(21), pp. 205-213.

8. Parameswara, AG (2018). Efficiency Analysis of Credit Distribution at Village Credit Institutions (LPD) in South Denpasar District. Warmadewa Economic Development Journal, 1-13.

9. Governor of Bali Regulation Number 44 of 2017. (nd). Regarding the Implementation Regulation of the Regional Regulation of the Province of Bali Number 3 of 2017 concerning Village Credit Institutions.

10. Purwasih, D. (2019). The Influence of the Implementation of the Internal Control Structure on the Efficiency of Credit Distribution at Rural Banks (BPR) in Badung Regency. Journal of Science, Accounting and Management, 62-100.

11. Rupadi, NM (2019). The Effect of Internal Control on the Efficiency of Lending at the Village Credit Institution (LPD) in Penebel District, Tabanan Regency. Denpasar: Faculty of Economics, Warmadewa University.

12. Suartana, I Wayan. 2013. Culture-Based Risk Based Audit at Village Credit Institutions (LPD) towards Sustainable Financial Inclusion. Denpasar: Quality Assurance Agency of Unud 2013.

13. Virnawan, IE (2014). Efficiency of Credit Distribution In Village Credit Institutions (LPD) In Marga-Tabanan District. Scientific Journal of Accounting and Business, 101-110.

14. Wilatini, KD, \&Wirakusuma, MG (2019). The Effect of Internal Control on Credit Efficiency in Village Credit Institutions (LPD) in Sukawati District, Gianyar Regency. E-Journal of Accounting, 874-902. 